\title{
パワーモジュールパッケージング技術の動向と課題
}

\author{
加柴 良裕*
}

\section{Trend and Challenges of Packaging Technologies for Power Modules}

Yoshihiro KASHIBA*

* 三菱電機株式会社（† 661-8661 兵庫県尼崎市塚口本町 8-1-1）

* Mitsubishi Electric Corporation (8-1-1,Tsukaguchi-Honmachi, Amagasaki, Hyogo 661-8661)

\section{1. まえがき}

パワーエレクトロニクス分野においては，地球温暖化防 止に向けて, 省資源・省エネルギの取り組みがより重要と なっている。したがって, 汎用インバータ, ハイブリッド カー, 風力発電などのパワエレ機器においては, 電気的特 性だけでなく耐環境性などに対する性能要求がより高まっ ている。それに伴い, パワーモジュールにおいては, 電流 制御や放熱, 絶縁などの基本性能と共に, 高温下での使用 や信頼性に対する改善が求められている。

このような市場要求に対して, パワーモジュールの構造 や動向に関して述べるとともに，より高い耐熱性や信頼性 を確保するための構造・プロセスに関して紹介する。

\section{2. パワーモジュールの動向}

パワーモジュールに用いられる IGBT (Insulated Gate Bipolar Transistor) は高耐圧かつ大電流が流せるパワーデバ イスであり, IGBT とダイオードを複数組み合わせて回路 を形成したパワーモジュールは, エアコンなどの民生品か

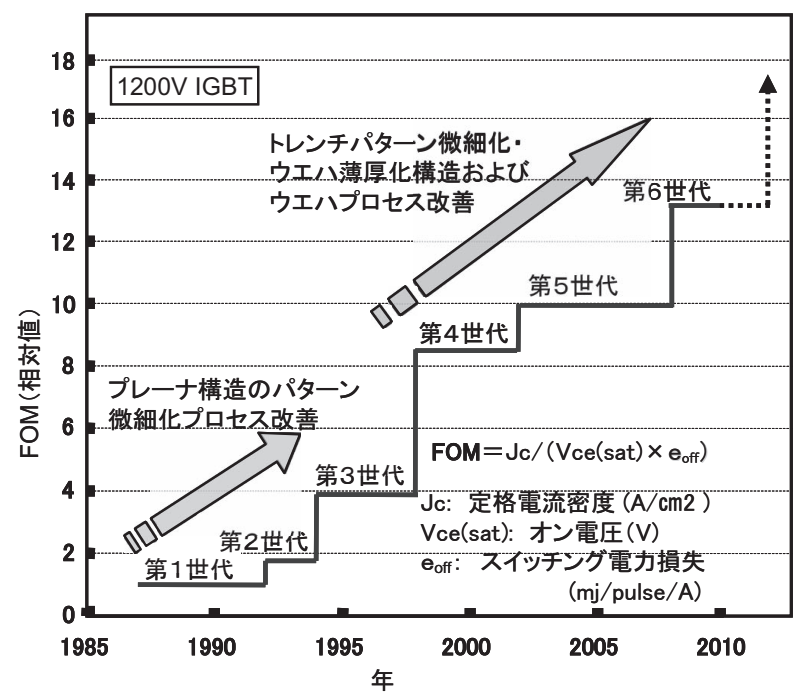

図 1. デバイス構造の進化によるIGBT 性能向上
ら電鉄用途まで幅広くパワエレ機器に用いられている。

図 1 にパワーモジュールのキーデバイスであるIGBT の 性能指数である FOM (Figure of Merit) の值を，第 1 世代を 基準として各世代の改善状況とそのためのキーテクノロ ジーを示す ${ }^{1)}$ 。FOM はパワーデバイスに流せる定格電流密 度を導通時の電圧（オン電圧）とスイッチング時の電力損 失で割ったものである。第 1 世代から第 3 世代のセル構造 はプレーナー構造で, パターンの微細化が進められた。第 4 世代でセル構造を溝（トレンチ）を形成するトレンチ構 造とし，セルサイズを大幅に縮小させた。第 5 世代では, 濃度プロファイルを進化させたキャリア蓄積トレンチバイ ポーラートランジス夕構造とした。さらに, 第 6 世代で は, トレンチ間隔の狭ピッチ化および薄ウエハ化が行われ た。このような構造の改善によってデバイス性能は大幅に 向上した。具体的には, パッケージの放熱設計に重要とな るパワーチップの発熱（電力損失）は第 6 世代においては 第 1 世代に比べて $1 / 4$ のとなっている ${ }^{2)}$ 。また, $\mathrm{SiC}$ デバ イスの実現により, 電力損失はさらに大幅に低減できると 思われる。これらのパワーチップの低損失化はパワーモ ジュールの小型化に貢献する。

パワーチップを複数搭載したパワーモジュールは, その 構造で分けると, 図 2 に示すように, 大電流や高電圧の主 に産業用途に用いられるゲル封止型と比較的小電流の主に 家電用途に用いられるモールド樹脂封止型に分けられる。

ゲル封止型パワーモジュールは小型化, 大容量化, 高放 熱化が進んでいる。この中でも，高放熱化の動きは構造の 大幅な変更を伴って進んでおり, 両面冷却 ${ }^{3)}$, 直接水冷 ${ }^{4)}$, 両面直接水冷 ${ }^{5)}$ などの新構造が開発されている。とくに, HEV 車などに用いられる水冷ヒートシンク一体型モジュー ルは，モジュールとヒートシンクを接続するための熱伝導 率の低いグリースを排除することができるため, 大幅な放 熱特性改善が図れる。一方，モールド樹脂封止型パッケー ジは 10 年間で約 $1 / 4$ のイズとなっているが，これはデバ イスの電力損失が $1 / 2$ になるとともに，パッケージの熱抵 抗が $1 / 2$ となったためである。熱抵抗低減には樹脂絶縁構 


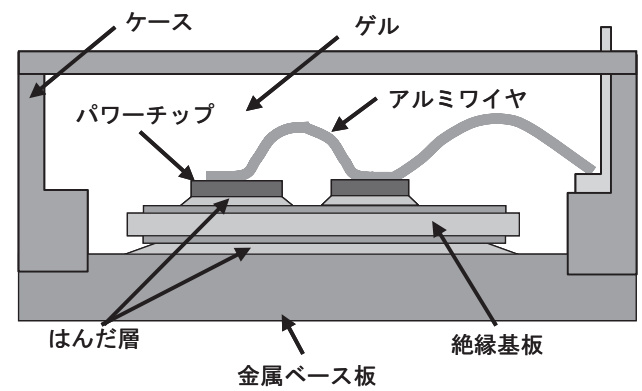

(a)ゲル封止型構造

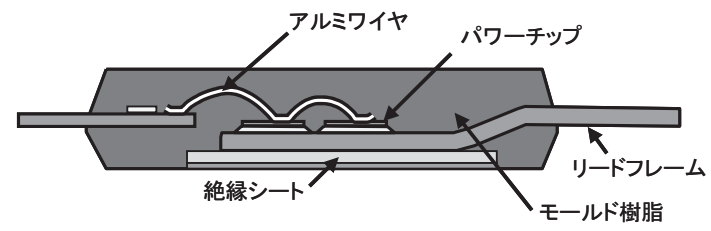

(b)モールド樹脂封止型構造

図 2.パワーモジュールの断面構造

造の変更 ${ }^{6)}$ やセラミック基板の採用などが有効である。

パワーチップの低損失化やパッケージの高放熱化に伴っ てパワーモジュールのパワー密度の向上は図 3 に示すよう に年々進んでいるが, 進化の先には損失を大幅低減できる $\mathrm{SiC}$ デバイスがあり，一段と小型化・高温動作化が進むと 考えられる。

\section{3. 接合部の高耐熱化・高信頼化}

近年, パワーモジュールに対する要求として, より厳し い環境下，たとえば高温となるエンジンルーム内での使用 や長寿命化などがあり，これに対して，耐熱・信頼性設計 が益々重要となっている。パワーモジュールでは, デバイ スの動作に伴う熱によってパワーチップ近傍やパワーモ ジュール全体の温度が変化することは避けられない。しか し, パワーモジュールは, 電気的回路形成, 放熱, 電気絶 縁の機能を発揮するため, 図 2 に示したように種々の材料 を複合化した構造をとっている。このような構造におい て, $\mathrm{Si}$ 半導体の線膨張係数 $2.3 \times 10^{-6} / \mathrm{K}$ に対し $\mathrm{Al}$ は $23 \times$ $10^{-6} / \mathrm{K}$, 絶縁基板は約 $10 \times 10^{-6} / \mathrm{K}, \mathrm{Cu}$ は $17 \times 10^{-6} / \mathrm{K}$ とそ れぞれ極めて差が大きいことから, 熱応力による疲労破壊 に対する信頼性設計が重要な課題となる。また, $500 \mathrm{~K}$ 程 度の高温下での使用を考えた場合, ケースやゲルなどの有 機材料やはんだ材料自身が劣化する危険性がある。ここで は, パワーモジュールの高耐熱化・高信頼化にとって重要 となる接合部に関して述べる。

チップ上の接合には主に $\mathrm{Al}$ ワイヤボンディング技術が用 いられる。ワイヤボンド部は超音波接合によってパワー チップ上の $\mathrm{Al}$ 電極と $\mathrm{Al}$ ワイヤを直接金属接合しているが, パワーチップの動作パターンに対応して比較的頻繁に温度 変化が生じる。この環境を加速評価する方法がパワーサイ

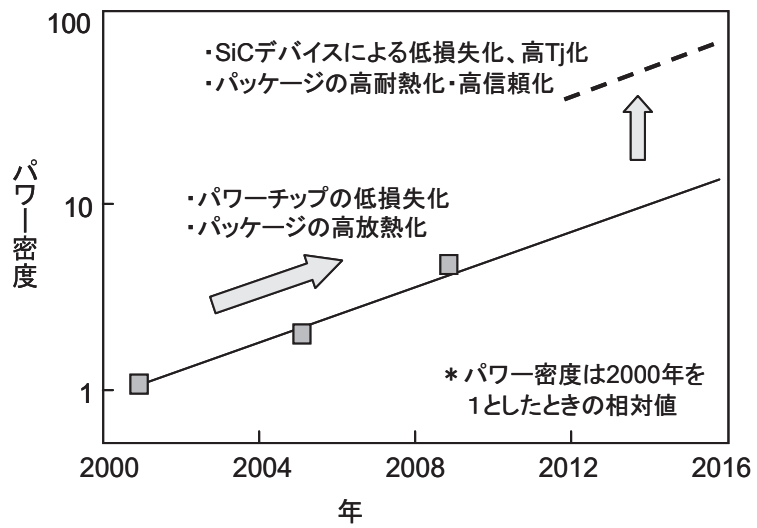

図 3. パワーモジュールの小型化の進展

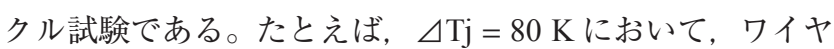
ボンド部は約 10 万サイクルの寿命を有している。この寿命 は温度スイング量によって大きく影響される。なお，この パワーサイクル寿命はワイヤの長さ, 本数, 配置, パワー チップの最高温度によっても影響を受ける。

一方, 最近では $\mathrm{Al}$ ワイヤに替えて $\mathrm{Cu}$ ワイヤを用いる長 寿命化方法も開発されている ${ }^{7)}$ 。 $\mathrm{Cu}$ は $\mathrm{A} 1$ に比べると低熱 膨張である，高電気伝導度である，というメリットを有す るが，剛性が高いためチップのダメージを防止する必要が ある。

また， $\Delta \mathrm{Tj}=80 \mathrm{~K}$ 時のゲル封止構造のパワーサイクル寿 命を 1 としてゲル封止構造とモールド樹脂封止構造の寿命 を相対比較した場合，モールド樹脂封止構造ではゲル封止 構造に比べ 3 倍程度長寿命となる。

さらに，パワーサイクルを向上させる方法としては配線

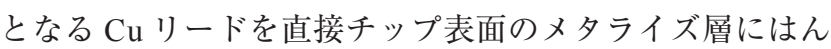
だ付する構造がとられる ${ }^{8)}$ 。このような配線構造とモール ド樹脂による封止構造を合わせて適用することによって， パワーサイクル寿命はゲル封止のワイヤボンディング構造 に比べると 10 倍程度まで伸びる。 $\mathrm{Cu}$ を接合する構造にお いては，通電時の発熱においてデバイス上の温度分布が広 がりかつ平坦化するため, 亀裂の進行が抑制できるものと 考えられる9)。

また，デバイスの動作温度が高くなった場合には，融点 の低いはんだ材は限界を迎える。すなわち，耐熱性の高い 材料で接合部を構成することが必要となる。図 4 は $\mathrm{Cu}$ 板 （厚さ $0.2 \mathrm{~mm}$ ) と Si の接合に薄膜を用いた場合の, SAT (Scanning Acoustic Tomograph) による信頼性評価結果であ る ${ }^{10)}$ 。接合部には $\mathrm{Cu}$ 板側に $4 \mu \mathrm{m}$ の $\mathrm{Sn}$ を, Si 側には $2 \mu \mathrm{m}$ の $\mathrm{Cu}$ と $4 \mu \mathrm{m}$ の $\mathrm{Sn}$ をそれぞれ蒸着して供給した。温度サ イクル条件は 313〜 448 K $(\Delta \mathrm{T}=135 \mathrm{~K})$, 保持時間は各 $2 \mathrm{~s}$ である。また，比較のため，高融点はんだである Sn-5Sbを 接合材として使用した場合の結果を示す。薄膜接合部は, $573 \mathrm{~K}$ で $300 \mathrm{~s}$ 保持することによって金属間化合物層となり 融点が上昇することが明らかとなっている。接合部の亀裂 
は SAT 像で白く表れるが，1,000 サイクルでの亀裂の進展 状況を比較すると，はんだ接合部では $50 \%$ 以上となってい る。これに対して, 薄膜接合部では一部亀裂が見られるも のの, ほほ健全な状態を維持できている。また, 接合界面 の断面観察によると，はんだ接合部は，はんだ内で破壊が 進行しているのに対して, 薄膜の場合は, 接合部に金属間 化合物が形成された結果, デバイス側の $\mathrm{Al}$ メタライズ層に 進展しており, より強度の低い材料が信頼性の律則となる ことが明らかとなっている。

チップ上以外で課題となる接合部はチップ下と絶縁基板 下の 2 箇所のはんだ付部となる。いずれの箇所においても 接合材料間の熱膨張差に起因する熱応力による破壊であ り，その寿命は，はんだのひずみ量と強い相関があること が知られている。たとえば, 絶縁基板下のはんだは 1 周期 60 分程度の比較的長い時間をかけて $233 \sim 398 \mathrm{~K}$ 間の温度 変化を与える温度サイクル試験によって亀裂が周辺部から 進展し, 最終的には剥離に至る。また, 亀裂進展の過程で パワーチップからの放熱経路が狭められる結果，パワー チップの熱破壊が生じるため, これを防止できるよう信頼 性設計を行う必要がある。

はんだひずみ量を低減させるには, 低熱膨張材料や低剛 性材料でモジュールを構成することで実現はできる。しか し，熱抵抗など他の特性への影響が大きくなるため，はん だ厚さを制御することによって，信頼性を確保することが 基本となる ${ }^{11}$ 。ただし，一定のはんだ量を供給したとして も $\mathrm{Cu}$ ベース板に対して絶縁基板が傾くことによって，は んだ厚さの薄い箇所が形成されると, 信頼性はこの箇所で 律則される。したがって，はんだ付部全領域で一定以上の はんだ厚さを確保することが重要な管理パラメータである。

さらに，はんだ接合部の耐熱性・信頼性を向上するため には，はんだ材料の機械的特性を己善することが有効であ る ${ }^{12)}$ 。Sn-3Ag-0.5Cuはんだに融点上昇と機械的特性改善の ため $\mathrm{Sb}$ 粉末を $7 \%$ 添加した材料の信頼性評価結果を図 5 に 示す。 $\mathrm{Si}_{3} \mathrm{~N}_{4}$ セラミックスの両側に $\mathrm{Cu}$ 板を接合したセラ

\begin{tabular}{|c|c|c|c|}
\hline \multirow{2}{*}{ 接合部構成 } & \multicolumn{3}{|c|}{ サイクル数 } \\
\hline & 0 & 1000 & 3000 \\
\hline $\begin{array}{c}\mathrm{Cu} \mathrm{Sn} \\
+ \\
\mathrm{Au}-\mathrm{Cu}-\mathrm{Sn} \mathrm{IMC} \\
\text { 接合時間 : } 1200 \mathrm{~s}\end{array}$ & & & \\
\hline $\begin{array}{c}\text { Cu3 } \mathrm{Sn} \\
+ \\
\mathrm{Cu} \\
\text { 接合時間 : } 3000 \mathrm{~s}\end{array}$ & & & \\
\hline $\begin{array}{l}S n-5 S b \\
\text { はんだ }\end{array}$ & & & \\
\hline
\end{tabular}

図 4.薄膜を用いた接合部の信頼性
ミックス基板と, $\mathrm{Ni}$ めしたた $\mathrm{Al}$ ヒートシンクを各はん だで接合し，233〜398 K の温度サイクル試験を行った。図 中示すように, 250 サイクル後で $\mathrm{Sn}-3 \mathrm{Ag}-0.5 \mathrm{Cu}$ ではクラッ クが大きく進展しているのに対して， $7.0 \% \mathrm{Sb}$ 粉末添加 Sn-3Ag-0.5Cu は 1/5 しか亀裂が進展していない。なお， Sb 粉末を添加したはんだの融点は添加なしの場合に比べ $8 \mathrm{~K}$ 上昇することも確認されており，材料の改善による耐熱 性・信頼性の向上が害証された。

パワーチップ下はんだ付部（ダイボンド部）の信頼性向 上のためにはモールド樹脂封止することが有効である。こ の構造では，はんだのひずみ量を比較的線膨張係数が大き いモールド樹脂も含めて構造体を形成するため, はんだの ひずみ量低減すなわち信頼性の向上が実現できる。

$\mathrm{SiC}$ デバイスなど高温で用いることができるデバイス対 応のダイボンド技術としては，Ag 焼結接合などはんだレス での接合技術も開発されている。 $\mathrm{Ag}$ 焼結接合の特徴として は $523 \mathrm{~K}$ 程度の低温で接合した接合部は $\mathrm{Ag}$ の融点までは 再溶融しないことであり, 耐熱性・信頼性の向上が期待で きる。図 6 は 233〜 448 Kの条件にて温度サイクルを 900 サ イクル加えた接合部の断面観察の結果である ${ }^{13)}$ 。焼結接合 部に大きな劣化は見られず，はんだに対して大幅に耐熱性 および信頼性が向上することが確認されている。

また，絶縁基板をヒートシンクと直接ろう付する構造も 耐熱性向上や信頼性向上にとって有効な手段となる ${ }^{4)}$ 。

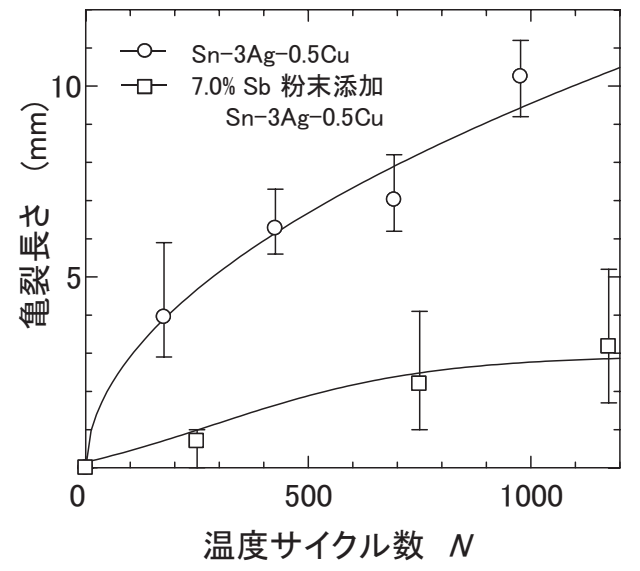

図 5. Sb 粉末添加による温度サイクル寿命の改善（233K〜 398K)

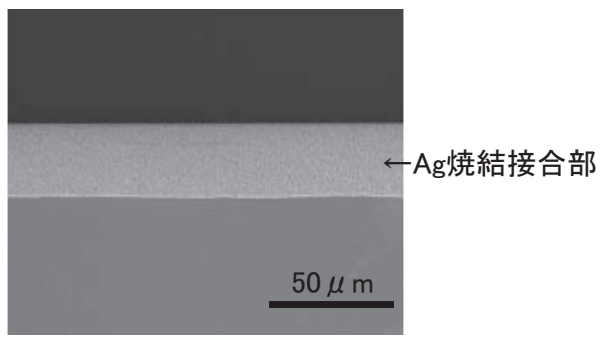

図 6. 温度サイクル試験後の断面（233K～448K，900 サ イクル) 


\section{4. まとめ}

温度的に過酷な状態下で使用されるパワーモジュールに 関して, ゲル封止構造やモールド樹脂封止構造の動向と耐 熱性・信頼性，およびワイヤボンド部やダイボンド部など 接合部の違いと耐熱性・信頼性に関して述べた。

パワーモジュールの小型・大容量化や使用用途の拡大に 合わせて, 信頼性設計は今後さらに重要となるものと思わ れる。また，パワーチップをより高い温度で動作させるた めには, 高性能パワーチップの開発と合わせてパッケージ の構造設計, 接合材料や絶縁材料の開発が必要となる。

さらには, Si デバイスの限界を打破する $\mathrm{SiC}$ デバイスの 実用化によって, さらにパワーモジュールの用途拡大が進 むものと期待される。

(2014.7.7- 受理)

\section{文献}

1）小野山, 他：“トレンチ IGBT の異物管理技術, ”三菱電機 技報, Vol. 84, No. 12, pp. 701-704, 2010

2) 加柴良裕, 他 : “パワーモジュールの電力損失低減と小型化 技術,”三菱電機技報, Vol. 83, No. 10, pp. 611-614, 2009

3) 坂本善次, 他: “車載用パワーエレクトロニクス製品の紐解 きと, 両面放熱パワーモジュールの実装技術, ” 溶接学会 誌, Vol. 80, No. 4, pp. 22-26, 2011

4) 吉松直樹, 他：“自動車用パワー半導体モジュール“J1 シ リーズ”のパッケージ技術, ”三菱電機技報, Vol. 88, No. 5, pp. $321-324,2014$

5) 中津欣也, 他：“環境対応自動車を支える次世代インバー夕 技術,” 日立評論, Vol. 94, No. 4, pp. 34-37, 2012
6) 佐野 耕, 他：“パワーモジュール用トランスファーモール ド超小型パッケージの開発,” Microjoining and Assembly Technology in Electronics, Vol. 14, pp. 327-330, 2008

7) A. Ciliox, et al.: "New module generation for higher lifetime," PCIM 2010, pp. 238-243

8) 中島 泰, 他：“リード接合を用いた大容量樹脂封止型パ ワーモジュール,” Microjoining and Assembly Technology in Electronics, Vol. 11, pp. 433-436, 2005

9) 菊池正雄, 他 : “ダイレクトリード接合型大容量パワーモ ジュール,”三菱電機技報, Vol. 84, No. 4, pp. 232-235, 2011

10) T. Fujimoto, et al.: "Bonding of Copper to Silicon Chips using Vapor-Deposited Tin Film,” ECO-MATE2011

11）林 建一, 他：“ワイヤバンプによるはんだ接合部長寿命化 技術の開発,” Microjoining and Assembly Technology in Electronics, Vol. 7, pp. 347-350, 2001

12）福田 敦, 他：“Sb 粉末を添加した Sn-3Ag-0.5Cuはんだの 接合信頼性,” Microjoining and Assembly Technology in Electronics, Vol. 20, pp. 241-246, 2014

13）日野泰成, 他：“高耐熱パワー半導体モジュールパッケージ ング要素技術, ”三菱電機技報, Vol. 88, No. 5, pp. 313-316, 2014

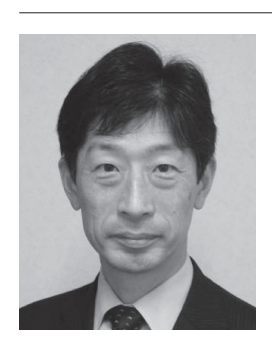

加柴良裕（かしば よしひろ）

著者紹介 1983 年大阪大学大学院工学研究科博士前期課程修 了, 同年三菱電機（株）生産技術研究所に入社。 2012 年より同社生産技術センター主管技師長㧍よ び大阪大学大学院工学研究科招へい教授。実装技 術開発に従事。博士 (工学)。溶接学会, スマー トプロセス学会会員。 